\title{
Biodrying under Greenhouse Conditions as Pretreatment for Horticultural Waste
}

\author{
Fabián Robles-Martínez ${ }^{1}$, Elizabeth M. Silva-Rodríguez ${ }^{1}$, Teodoro Espinosa-Solares ${ }^{2,3}$, \\ Belem Piña-Guzmán $^{1 *}$, Carmen Calixto-Mosqueda ${ }^{1}$, Francisco J. Colomer-Mendoza ${ }^{4}$, \\ Enrique Durán-Páramo ${ }^{1}$
}

\begin{abstract}
${ }^{1}$ Unidad Profesional Interdisciplinaria de Biotecnología, Instituto Politécnico Nacional, Mexico City, Mexico; ${ }^{2}$ Gus R. Douglass Institute, West Virginia State University, South Charleston, USA; ${ }^{3}$ Departamento de Ingeniería Agroindustrial, Universidad Autónoma Chapingo, Texcoco, Mexico; ${ }^{4}$ Departamento de Ingeniería Mecánica y Construcción, Universitat Jaume I, Castellon, Spain.

Email: ${ }^{*}$ apinag@ipn.mx
\end{abstract}

Received February $2^{\text {nd }}, 2012$; revised February $2^{\text {th }}, 2012$; accepted March $31^{\text {st }}, 2012$

\begin{abstract}
The biodrying process was studied as an alternative technology to reduce the mass and volume of horticultural waste. Four static piles were prepared inside a greenhouse: two containing whole waste and two consisting of shredded waste. All the piles were compared with a test pile containing whole waste and placed outside the greenhouse. In two cases, ventilation ducts were installed to improve aeration. Each greenhouse was $2.0 \mathrm{~m}$ wide, $3.5 \mathrm{~m}$ long and $1.16 \mathrm{~m}$ high. The air temperature and relative humidity were monitored both inside and outside the greenhouse. Mass, humidity, organic matter and total nitrogen in the waste were measured. Piles inside the greenhouse showed decreases of $80 \%$ and $75 \%$ in weight and volume, respectively, during the first 16 days. The data obtained in this work suggest that biodrying could improve the handling and transport of horticultural waste while also minimizing the impact of pollutants.
\end{abstract}

Keywords: Solid Waste; Aerobic Degradation; Stabilization; Greenhouse

\section{Introduction}

Nowadays, there are more than 60 distribution centers of fresh food products ("Centrales de Abasto") operating in Mexico. Together, they produce thousands of tons of horticultural waste every day, which rots easily because it is organic matter and has high water content. The biggest distribution center of fresh food in Mexico City generates close to 585 tons of damaged and spoiled fruits, vegetables and flowers daily. Most of this waste is disposed of in landfills without any kind of pretreatment or recovery process [1].

Horticultural waste can be treated by an aerobic process like composting or biodrying. Biodrying, which is a fairly recent development in the field of waste management, is a treatment that uses forced aeration along with the heat generated by natural aerobic bioconversion of some organic matter to dry the waste. Most of the biological heat produced is utilized to evaporate surface and bound water associated with the waste matrix.

The most obvious advantage of biodrying is the reduction in odor, volume, and weight of the waste, which in turn may improve handling, transport and disposal of

"Corresponding author. organic waste when a high volume of waste is an issue. Furthermore, biodrying has also been proposed as an effective means of eliminating some pathogens [2].

As reported previously [3], a controlled air supply can be used to increase the drying rate, which in turn increases the rate of water evaporation. However, the velocity and temperature of the air must be controlled adequately, because the aim of biodrying is to achieve satisfactory water loss in order to obtain a homogeneous, stable and useful product [4]. Biodrying is typically carried out in tunnels or biological reactors, where air is supplied and the ideal conditions of temperature and humidity are maintained to ensure a balance between the drying rate and the aerobic degradation of the organic matter [4-6].

Currently, most studies dealing with the biodrying process focus on reducing the water content of municipal solid waste while preserving its calorific power, in order to obtain a refuse-derived fuel [4,6-8]. Other applications of biodrying have also been researched; for instance, Navaee-Ardeh et al. [9] reported that biodrying is an attractive technique for drying sludge from the paper industry.

In the last few decades, a number of researchers have studied the production and collection of biothermal en- 
ergy obtained from compost of different kind of organic wastes, to be used in growing plants in greenhouses [10], in heating bedrooms in home $[11,12]$. Conversely and according to the open literature, no reports have been published on the potential use of the heat of greenhouses, as an efficient collector of solar energy, to improve biodrying of horticultural waste. Thus, in this work, the biodrying process, conducted under both environmental and greenhouse conditions, was studied to evaluate whether it can be considered as an alternative to reduce the mass of horticultural waste in a short period of time in order to enhance handling, transportation and final disposal capacities.

\section{Material and Methods}

\subsection{Feedstock Characteristics}

The horticultural waste feedstock was sampled from the biggest market of fresh food products in Mexico City, the "Central de Abasto de la Ciudad de México". It consisted of a mixture of different kinds of vegetable waste, lettuce being the most common product. The trials were performed in small greenhouses constructed as shown in Figure 1. Each greenhouse was $2.0 \mathrm{~m}$ wide, $3.5 \mathrm{~m}$ long and $1.16 \mathrm{~m}$ high and was based on a metallic framework. This metal structure of the greenhouse was covered with a white long-life polyethylene film with a thickness of 180 microns. In order to improve the biodrying process, the front and the back of the polyethylene film were re- moved daily for one hour. In order to provide oxygen and allow air to penetrate and move through the pile by passive convection and diffusion, ventilation ducts were placed in some of the piles as indicated in Table 1; the size of the ducts were $0.25 \mathrm{~m}$ high and $2.5 \mathrm{~m}$ long.

\subsection{Sampling Locations}

Five static biodrying piles containing between 221 and $325 \mathrm{~kg}$ of horticultural waste were prepared as shown in Table 1. Air temperature and relative humidity were monitored inside and outside the greenhouse. Pile temperature was measured with a long-stemmed thermometer both in the center (approximately $15 \mathrm{~cm}$ below the surface) and in the peripheral zone, and data were recorded daily for 35 days. Samples of $10 \mathrm{~g}$ of horticultural waste were taken from the center of the piles and used to evaluate water, organic matter and nitrogen contents.

\subsection{Measured Parameters and Measurement Methods}

Mass loss, humidity, organic matter and total nitrogen in the waste were measured. Moisture and dry matter content were determined daily by a gravimetric method in compliance with the Mexican standard procedure established by NMX-AA-16-1984 [13]. Briefly, samples weighing between 3 and $5 \mathrm{~g}$ were put in an oven at $60^{\circ} \mathrm{C}$ (CR1-2 Shel Lab Cleanroom Oven) for about 2 hours and allowed to cool to room temperature in desiccators. They
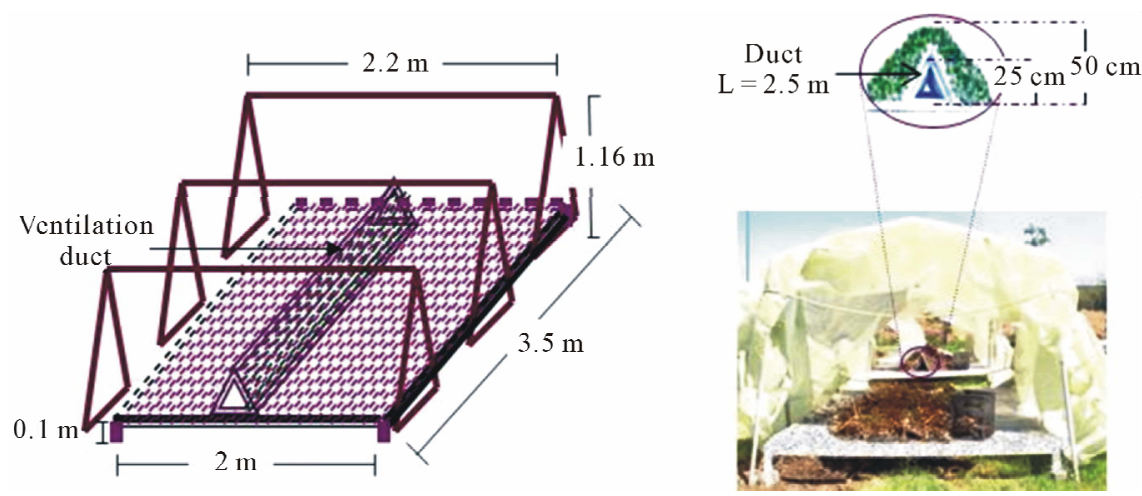

Figure 1. Experimental setup.

Table 1. Operational conditions of biodrying assays.

\begin{tabular}{ccc}
\hline Pile & Initial mass $(\mathrm{kg})$ & $\begin{array}{c}\text { Characteristics } \\
\text { (Waste integrity/Ventilation/Surroundings) }\end{array}$ \\
\hline 1 & 284.5 & Whole waste/ventilation duct/in greenhouse \\
2 & 221.1 & Shredded waste/ventilation duct/in greenhouse \\
3 & 324.8 & Whole waste/no ventilation duct/in greenhouse \\
4 & 254.5 & Shredded waste/no ventilation duct/in greenhouse \\
5 & 279.6 & Whole waste/no ventilation duct/under environmental conditions \\
\hline
\end{tabular}


were then weighed and heated again for about 2 hours, after which the sample was cooled and weighed a second time. The procedure was repeated until the weight difference between two successive operations was less than $0.01 \%$.

Total Nitrogen was measured by the Kjeldahl method on wet material [14]. Organic matter was quantified, in accordance with the Mexican standard procedure [15], by applying the Watley-Black colorimetric method. Briefly, three $0.1 \mathrm{~g}$ samples of horticultural waste were treated with $0.1 \mathrm{~N}$ potassium dichromate $(99.9 \%$ pure, J. T. Baker) as a strong oxidizing agent in sulfuric acid $(98 \%$ pure, Reasol). The mixture was swirled vigorously for 1 minute and allowed to stand on a heat proof surface for 30 min to allow oxidation of the organic matter to proceed. Distilled water and phosphoric acid (95\% pure, Reasol) and diphenylamine (J. T. Baker) were then added as an indicator solution. When the reaction was completed, unreacted dichromate was titrated by adding 0.5 $\mathrm{N}$ ferrous sulfate (J. T. Baker).

\section{Results and Discussion}

\subsection{Evolution of Weight and Water Content during Biodrying}

Based on the results presented in Figure 2, it was estimated that in the first two days, whole and shredded waste lost $15 \%$ and $20 \%$ of their water content, respecttively, as leachate. This rapid loss of water during this short period was due to lixiviation by hydrolytic decomposition as a result of partial degradation of the organic matter, since water in horticultural waste can be released as leachate when the wall or membrane cells are degraded, as reported previously [16]. Next, the heat generated in the pile as a by-product of the microbial breakdown of organic material acts as the energy for evaporation. As in composting, in biodrying most of the energy released during microbial activity is used to evaporate water from the waste materials. Then, following the hydrolytic stage, evaporation helped to diminish water content in the horticultural waste; consequently, the weight of the waste had diminished by $82 \%$ in the four piles inside the greenhouse on day 16. Nevertheless, the weight reduction observed in the control pile was only $22 \%$ over the same period of time, compared with the initial weight.

Our results showed that while drying, waste did not lose water at a constant rate and the rate of water removal under fixed conditions dropped off as drying progressed. At the beginning of biodrying and for some time thereafter, water generally continued to be lost from the waste at a constant rate. This was followed by an inflection in the drying curve, which leads to the period in which the drying rate drops [17]. During the initial period of the drying

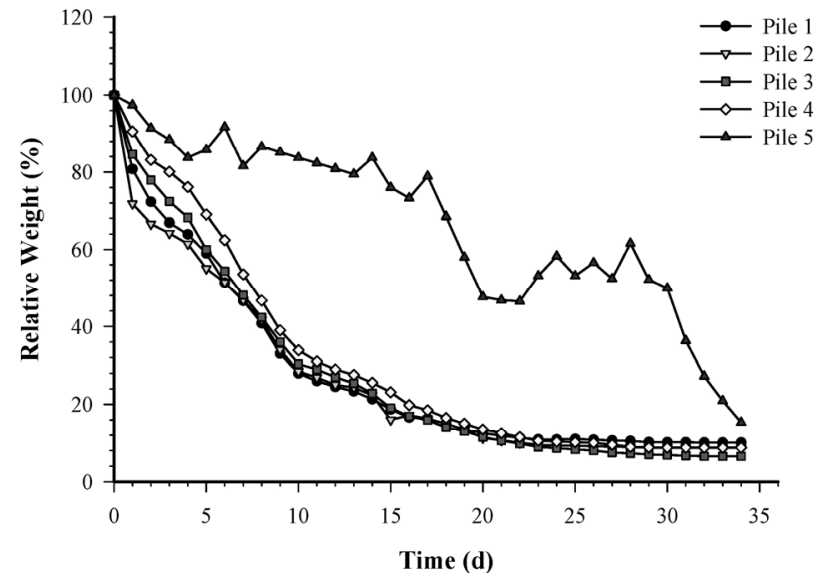

Figure 2. Weight loss of horticultural solid waste during biodrying.

process (constant velocity), the heat is transferred to the product and to the contained moisture.

In the next phase of the drying process, free moisture persists on the surfaces and the rate of evaporation alters very little as the moisture content is reduced. There is a gradual and relatively small increase in the product temperature during this period [18]. Initial water content was $95 \%$. According to results, it could be inferred that for all the piles inside the greenhouse, waste humidity is reduced at two drying rates: 1) the constant rate of drying, where the fastest decrease in waste humidity (from 95\% to $18 \%$ ) was attained in a short time (16 days); and 2) the falling rate of drying, where more time (19 days) was required to remove another $9 \%$ from the remaining water (from $18 \%$ to $9 \%$ ). The weight loss curve of the piles in the greenhouse became asymptotic on day 24 , which means that the material reached the equilibrium state with the surroundings. Thus, zero moisture content was never achieved, which is a similar behavior to that reported by N. K. Thakur and N. S. Thakur [17]. In the control pile, the maximum decrease was reached at the end of the experiment ( 35 days). The reason for this is that the control pile was often re-humidified by rain and condensing phenomena at dawn, above all on rainy days (days 5 and 21 ), since this pile was kept under outdoor conditions.

\subsection{Loss of Organic Matter during Biodrying}

During biodrying, weight loss results from a reduction in water content and, to a lesser extent, from partial degradation of organic matter. As depicted in Figure 3, during the first 16 days the organic matter content was reduced from $80 \%$ to $50 \%$, which coincides with the period of high microbial activity. The rest of the time the reduction was lower (from $50 \%$ to $38 \%$ ). In the control pile, a bigger reduction was observed in the organic matter content (from $80 \%$ to $20 \%$ ) because the pile was constantly 


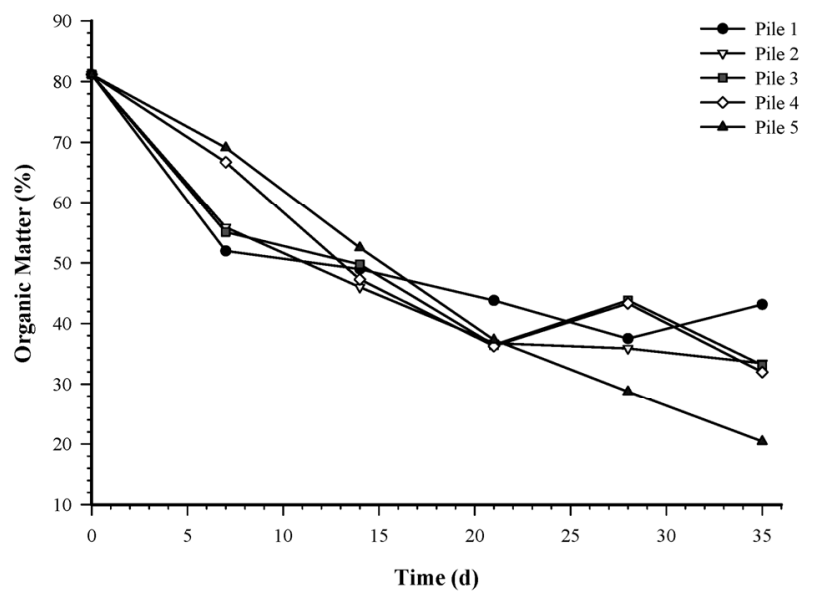

Figure 3. Reduction of organic matter during biodrying.

re-humidified (by the rain), thus allowing the microbial activity to continue throughout the experiment.

\subsection{Influence of Climate on Biodrying}

Due to changes of climate, the air and waste temperatures inside the greenhouse varied during the experiment. Since all the piles in the greenhouse behaved in a similar manner (Figure 2), pile 1 was taken as being representative of all of them. The changes in solid waste, together with indoor and outdoor air temperatures are shown in Figures 4 and 5. The highest temperatures of waste inside the greenhouse were observed during the first three days, when they exceeded the greenhouse temperature (Figure 4). In this period, microbial activity was more intense. The lowest greenhouse temperatures $\left(17^{\circ} \mathrm{C}\right)$ were found on days 5 and 6 , when the environmental temperature descended to $10.4^{\circ} \mathrm{C}$, which affected the waste temperature and therefore the performance of the process. After that time, waste temperature increased again but never exceeded the air temperature inside the greenhouse, although most of the time it was higher than the environmental temperature.

There was a variable difference in temperature $(\Delta T)$ from day 1 to day 15 , between the inner and outer layers of the waste piles inside the greenhouse. This suggests that the biodrying process ends on day 16 (case of pile 1) when the surface and center pile temperatures became equal (Figure 5).

\subsection{Advantages of Biodrying in Greenhouse}

The drying process in a greenhouse results in two main effects:

1) Generation of metabolic heat due to the aerobic microbial activity in the waste. Such a metabolic effect is responsible for the process called biodrying, as stated by some authors [6,7]. As a consequence of heat generated by the intense microbial degradation, the waste tempera- ture was higher than the greenhouse temperature during the first three days and on the sixth day (Figure 4).

Biodrying piles reached temperatures between $29^{\circ} \mathrm{C}$ and $37^{\circ} \mathrm{C}$ during the first four days. The thermophilic phase (above $45^{\circ} \mathrm{C}$ ) was not reached because of the low volume of the piles, and the water content was excessively high. In this case the heat derived from the biodegradation was not enough for water evaporation, as suggested by Zhang et al. [16].

2) Solar energy stored as heat inside the green house that helped to increase mainly the air temperature but also to a lesser extent the waste temperature. On the other hand, the temperature and relative humidity, both of which were higher in the greenhouse than in outdoor conditions, could have a positive effect on microorganisms in waste by improving microbial growth and activeity, mainly in the case of fungi. In addition, the greenhouse protected the piles from the rain, thereby preventing the horticultural waste from being re-humidified.

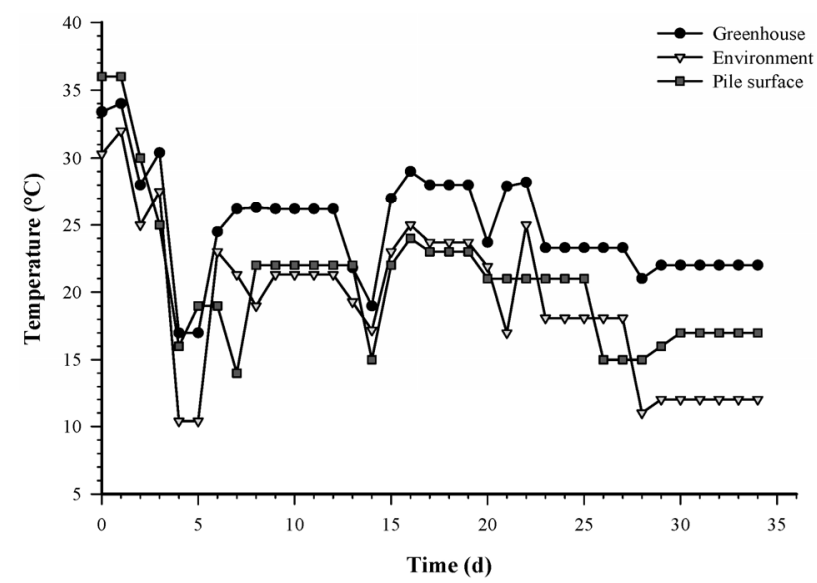

Figure 4. Temperature behavior in greenhouse, environment and pile surface.

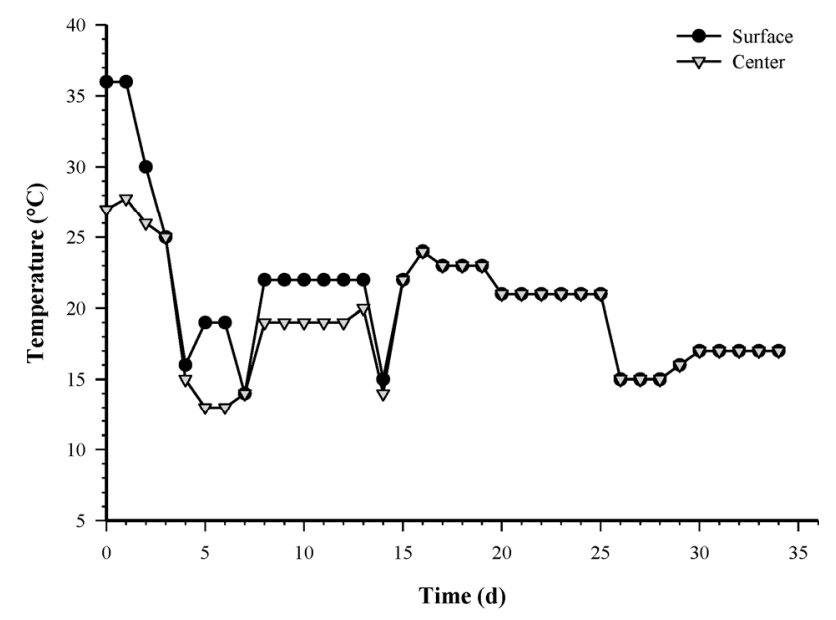

Figure 5. Evolution of internal and surface temperatures of solid waste. 


\subsection{Physicochemical Characteristics of Biodried Horticultural Waste}

The physicochemical characteristics of horticultural waste before and after the biodrying process are shown in Table 2.

The initial humidity of the horticultural waste at the beginning of the process was $95.5 \%$, while at the end of the process it was between $3 \%$ and $6 \%$. Such a large reduction in humidity and partial biodegradation of organic matter resulted in a mass reduction above $90 \%$ at the end of the process ( 35 days). Considering that the biodried horticultural waste was partially stabilized, it is possible to infer that the material could be used as organic amendments for soils. Further work is needed to evaluate the influence of this material in crops.

\section{Conclusion}

The final weight, volume and humidity values achieved in this work allow us to suggest biodrying as a pretreatment of horticultural waste in order to improve the capacity for handling, transportation and final disposal of horticultural waste without giving rise to pollution problems. The novelty of carrying out the biodrying process in a greenhouse lies in the fact that the heat of the enclosure and the energy resulting from microbial activity in horticultural waste raise the efficiency of the performance of water removal and water content reduction in waste. Biodrying in greenhouses could be proposed as a technology to stabilize waste with high water content, like the refuse produced by important fresh food markets. Nevertheless, since air moving through the compost pile (either by forced ventilation or passive convection and diffusion) gets hot and evaporates water from the surfaces of particles, further work is needed to evaluate the influence of forced airflow on biodrying kinetics in a greenhouse and performance in piles with a larger volume. Such work will make it possible to lower the time needed to reach target moisture contents and to evaluate whether thermophilic temperatures could be achieved

Table 2. Physicochemical parameters of waste during biodrying.

\begin{tabular}{lcccc}
\hline \multirow{2}{*}{ Parameter } & \multicolumn{2}{c}{ Piles in greenhouse } & \multicolumn{2}{c}{ Control pile } \\
\cline { 2 - 5 } & $\begin{array}{c}\text { Initial value } \\
(\%)\end{array}$ & $\begin{array}{c}\text { Final value } \\
(\%)\end{array}$ & $\begin{array}{c}\text { Initial value } \\
(\%)\end{array}$ & $\begin{array}{c}\text { Final value } \\
(\%)\end{array}$ \\
\hline Humidity & 95.48 & $3-6$ & 95.48 & 14.6 \\
Volume & 100 & 25 & 100 & 42 \\
Mass & 100 & $5-9$ & 100 & 18 \\
Organic Matter & 81.16 & 40 & 81.16 & 20 \\
N content & 1.99 & $1.25-1.75$ & 1.99 & 1.25 \\
\hline
\end{tabular}

during the processes.

\section{Acknowledgements}

The authors acknowledge financial support from the Instituto Politécnico Nacional (SIP and COFAA). We particularly wish to thank Ricardo Estrada Núñez from the Mexico City Government (DGSU) and Rogelio Bailón Morales from the IPN compost plant in Mexico.

\section{REFERENCES}

[1] Secretaria del Medio Ambiente, "Inventario de Residuos Sólidos del Distrito Federal 2008," Secretaría de Medio Ambiente, Gobierno del Distrito Federal, México City, 2010.

[2] P. Wright and S. Inglis, "Biodrying Dairy Manure," Proceedings of the 2002 International Symposium on Composting and Compost Utilization, Colombus, 5-7 May 2002, pp. 996-1007.

[3] A. Kumar and G. N. Tiwari, "Thermal Modelling of a Natural Convection Greenhouse Drying System for Jaggery: An Experimental Validation," Solar Energy, Vol. 80, No. 9, 2006, pp. 1135-1144. doi:10.1016/j.solener.2005.09.011

[4] F. Adani, D. Baidoa, E. Calcaterra and P. Genevinia, "The Influence of Biomass Temperature on BiostabilizationBiodrying of Municipal Solid Waste," Bioresource Technology, Vol. 83, No. 3, 2002, pp. 173-179.

doi:10.1016/S0960-8524(01)00231-0

[5] M. Sugni, E. Calcaterra and F. Adani, "BiostabilizationBiodrying of Municipal Solid Waste by Inverting AirFlow," Bioresource Technology, Vol. 96, No. 12, 2005, pp. 1331-1337. doi:10.1016/j.biortech.2004.11.016

[6] A. C. Velis, P. J. Longhurts, G. H. Drew, R. Smith and S. J. T. Pollard, "Biodrying for Mechanical-Biological Treatment of Wastes: A Review of Process Science and Engineering," Bioresource Technology, Vol. 100, No. 11, 2009, pp. 2747-2761. doi:10.1016/j.biortech.2008.12.026

[7] E. C. Rada, M. Ragazzi, V. Panaitescu and T. Apóstol, "MSW Bio-Drying and Bio-Stabilization: An Experimental Comparison," Proceedings of the International Conference: Towards Integrated Urban Solid Waste Management System, Buenos Aires, 6-10 November 2005, pp. 1-10.

[8] J. Dach and S. Bode, "Biological Drying of Biowaste to Generate Biomass," ORBIT 2006 5th International Conference, Biological Waste Management, from Local to Global, Weimar, 13-15 September 2006, pp. 859-866.

[9] S. Navaee-Ardeh, F. Bertrand and P. R. Stuart, "Emerging Biodrying Technology for the Drying of Pulp and Paper Mixed Sludges," Drying Technology, Vol. 24, No. 7, 2006, pp. 863-878. doi:10.1080/07373930600734026

[10] S. Diver, "Compost Heated Greenhouses. NCAT Agriculture Specialist. Appropriate Technology Transfer for Rural Areas. U.S. Department of Agriculture,” 2001. http://www.mans.edu.eg/projects/heepf/ilppp/cources/12/ pdf\%20course/45/how/compostheatedgh.pdf 
[11] I. Pain and J. Pain, "The Methods of Jean Pain or Another Kind of Garden," Committee International Jean Pain, Brussels, 1972.

[12] J. W. White, "Letters to the Editor. BioThermal Update (BTU)," BioThermal Energy Center, Portland, 1982.

[13] NMX-AA-16, "Protección al Ambiente-Determinación de Materia Orgánica. Environmental Protection-Soil Contamination Municipal Solid Residues - Organic Matter Determination," 1984.

http://www.pensaryhacer.org.ar/cursosambiente/archivos/ norma03.pdf

[14] J. B. Jones, B. Wolf and H. A. Mills, "Plant Analysis Handbook," Micro-Macro Publishing, Athens, 1991.

[15] NMX-AA-021, "Protección al Ambiente-Determinación de Materia Orgánica. Environmental Protection-Soil Contamination Municipal Solid Residues-Organic Matter
Determination," 1985. http://148.206.53.231/bdcdrom/GAM06/GAMV15/root/d ocs/NMX-082.pdf

[16] D. Q. Zhang, P. He, L. Shao, T. Jin and J. Han, "Biodrying of Municipal Solid Waste with High Water Content by Combined Hydrolytic-Aerobic Technology," Journal of Environmental Sciences, Vol. 20, No. 12, 2008, pp. 1534-1540. doi:10.1016/S1001-0742(08)62562-0

[17] N. K. Thakur and N. S. Thakur, "Drying of Fruits and Vegetables," In: L. R. Verma and V. K. Joshi, Eds., Postharvest Technology of Fruits and Vegetables: Handling, Processing, Fermentation and Waste Management, Indus Publishing Company, New Delhi, 2000, p. 835.

[18] D. A. Traub, "The Drying Curve," 2002. www.process-heating.com/PH/Home/Files/PDFs/0902ph _dryingfiles.pdf 